\title{
THE PORTRAIT OF RURAL TOURISM MODEL IN THE BAHA TOURISM VILLAGE OF BADUNG DISTRICT
}

\author{
Monica Fitria Hartiningsih, I Made Adhika, Komang Trisna Pratiwi Arcana. \\ STPBI, Udayana University, STPBI \\ monicafitria_hartiningsih@gmail.com, adhika20022002@yahoo.com, \\ trisnapratiwi.arcana@gmail.com
}

\begin{abstract}
Baha Village designated as tourism village since 1994. However, until now relatively undeveloped as expected. The purpose of this research to determine of tourism existing and the portrait of rural tourism model that took place in Baha Tourism Village. This research used descriptive qualitative method. The informant determined by purposive and utilize qualitative and quantitative data where its sourced from primary data also secondary data. Datas obtained by observation, interviews, and documentation. The research of result was found tourism existing ini Baha Tourism Village in the form of a panoramic expanse of rice fields and visiting to a Balinese traditional house, supported with the adequate accessibility and facilities such as public toilets, wantilan, clean water, electricity and communication networks. Institutional is not yet operational. Baha Tourism Village life cycle stage with the involvement of public attitudes tend to be quiet(Withdrawal). Referring to the existing portrait of rural tourism model at the Baha Tourism Village is a rural tourism model of halffull-passive interaction who initiated by the government and its managed by the individual societies. It can be concluded, Baha Tourism Village has not been categorized as a ideal tourism village.
\end{abstract}

Keywords : Baha Tourism Village, Rural Tourism Model, Portrait.

\section{Introduction}

The tendency of social phenomena is rife in the practice of mass-based tourism. Mass tourism tend to see development of tourism in quantity. More and more tourists visit, the better the development of the tourism industry. Business and investors do a lot for development of infrastructure in order to achieve the satisfaction of tourists, but on the other hand the existence of the neglected, exploited natural resources to support tourism infrastructure. The tendency of local communities that have minimal economic capital only act as spectators or workers in the land of his ancestors (Nugroho, 2014). It takes the right solution to the phenomenon of today. This solution is known as alternative tourism. One form of alternative tourism are rural tourism. Rural tourism into a new development in the world tourism industry. Rural tourism in some countries such as Malaysia, South Africa, Spain, UK, USA, Japan, Portugal, and Australia tourism as a stimulant which is able to revitalize the rural economy (Sewoyo, et al, 2011). 
Tourism Village is one of the products of rural tourism. Tourism Village is developed on the basis of uniqueness of the community thus giving rise to a variation like the village, which focuses on the beauty of natural landscapes, unique flora and fauna, agriculture or fisheries activities, cultural arts and skills and other charms. Tourism Village is also an alternative tourism that can contribute to positive changes for social resources, economy and culture in rural areas (Damanik in Suryawan, et al, 2016).

Bali has become a major tourist destination in Indonesia, and have long been the belle of the tourism sector, foreign exchange (Pujaastawa, et al, 2005). Contributions to the practice of tourism in Bali in fact dominated by the Badung regency rather focused on a region of South Bali. South Bali region like South Kuta District into a tirta region, center star hotels and restaurants as well as a meeting place and a national and international events with mass tourism-based development. In an effort to equitable economic and social welfare of Badung, the local government set up a development policy which is viewed by that topography. Of development policy, local governments create a diversified tourism product in the form of alternative tourism in the form of a tourist village. Determination of the tourist village is listed Peraturan Bupati Badung No. 47 Tahun 2010 about The Establishment of Tourism village in Badung.

One of that has been set is the Baha Tourism Village. Baha village has actually been launched since 1992 and designated as a Tourism Village by Surat Keputusan Bupati Kepala Daerah Tingkat II Badung Nomor 2028 Tahun 1994. Furthermore, there is also an update regulation for the establishment of the Tourism Village Baha namely through Peraturan Bupati Badung No. 7 Tahun 2005 regarding the determination of the object and attractions (Muliadiasa, 2008). In 2010 too, the regent passed a law back in the Peraturan Bupati Badung No. 47 Tahun 2010 which contains the determination of 11 (eleven) tourism village in Badung and one of them is the Baha Tourism Village. However, since the Baha village designated as Tourism Village in 1994 until today, was relatively undeveloped in accordance expectations as a tourist village. Powered by phenomena that tourists who come just passing and visited several homes of local people in a short time and then resumed his journey (Samiarta, 2015). Moreover, if the development of the Baha Tourism Village Baha compared with other tourism village in Badung regency which has developed as Pelaga Tourism Village and Belok Sidan Tourism Village (Suryawan, et al, 2016). Based on this phenomenon, this research is important to know the existing of tourism and portrait of rural tourism models in Baha Tourism Village.

\section{Literature Review}

\section{Tourism Product Components}

In an effort to understand the development of tourism in general, this study adapted the framework of Buhalis 6A destination attribute (2000), which became the development of the concept of tourism product components. Buhalis (2000) categorizes as follows: (1) Attractions (Attractions), which includes natural, synthetic, artificial buildings, and special events; (2) Accessibility (accessibility), which includes the transport system, terminals, and modes of transportation; (3) Amenitas (amenities) provided such as accommodation, food and beverage 
providers of business or catering, retail and other travel services; (4) Support Services (ancillary services), which refers to the other services that can support the needs of travelers in these destinations such as banks, telecommunications, postal services, hospitals, and infrastructure are the services provided by the institutional tourism in tourist destinations the; (5) Activity (activities) that all the activities that can be carried by travelers when in these destination; (6) Package tours are available (packages available) that the tour packages that have been prepared by a tour operator or a travel bureau (BPW). Components of tourism products is quite ideal to describe the tourism product in the village of Baha and support the research in the search for a model of rural tourism with the approach of the characteristics of tourism products.

\section{Tourist Destination Life Cycle}

Development of a tourism destination can be described in a life cycle. Tourist Destination Life Cycle introduced Butler (in Sewoyo, et al, 2011). Stages of development is an evolutionary cycle stages that occur in the development of tourism. Butler (in Sewoyo, et al, 2011) there are seven phases of the development of tourism or tourism life cycle (Destination area Lifecycle) the implications and impacts of different.

First there Exploration phase (exploration / discovery). At this stage, the number of tourists is still very little generally allocentrics type and explorer. Infrastructure is very minimal or no. Tourist attraction on offer is a natural and pristine culture. Second, phase Involvement (Engagement. At this stage it started no investment community for basic facilities of tourism, tourists are still rare. Promotion has been done on a small scale. The government started to invest in costly infrastructure. Furthermore, phase Development (Development). This stage show rapid growth in the number of visits, even the number of tourists can be greater than the number of locals. Sources tourist market has been formed with advertising that is very intense. Investments start from the outside of the control of local communities began to decline. The appeal of artificial started to be built, while tourists midcentris began to replace the rating explorer and allocentris. Fourth, the Consolidation Phase (Consolidated), this phase describes the rate of growth began to slow down, began to think to reduce seasonality and attract new market share. Travelers psychocentris started coming in and the population began to appreciate the importance of tourism. Fifth, the phase of stagnation (Stability / Fixed), this stage showed the highest number of visits related to the capacity limit has been reached. Could happen tourist destination began to rely on repeaters and occupancy rates start low. In the phase of stagnation, there are two phases of the derivative. First, the phase Decline (Reduced). At this stage the number of tourists and distribution (spatial) tourists began to decrease. Tourist activity began to decrease even move to another place, while the tourism infrastructure is getting worse. Lastly, phase Rejuvenation (Rejuvenation) is characterized by the emergence of a new attraction of new natural resources.

In this research, Tourist Destination Life Cycle Theory proposed by Butler (in Sewoyo, et al, 2011) was used as a analysis theory to determine the position of tourism in terms of life cycle stages or destinations Tourism Village Baha. 


\section{Evolution of Public Attitudes toward Tourism}

In connection with the evolution of public attitudes towards tourists, Doxey (in Pitana, 2005) have developed a theoretical framework called irridex (irritation index). Irridex theory of Doxey illustrates change local attitudes towards tourists linearly. The stages of public attitudes to tourism developed by Doxey and illustrated by Fridgen (in Sewoyo, et al, 2011) are as follows: (1) Euphoria depicts the early days of development, the community welcomed the arrival of tourists and take the economic benefits of tourism develop; (2) Apathy illustrates the increasing tourist arrivals and some changes occur in the environment where people live, people started to show negative attitudes and tourists choose not to stay long in the environment; (3) Annoyance characterized by tourism growth continues, people become marginalized because of the increasing number of tourists who come and attention of various parties are given only for tourism; (4) antagonism meggambarkan destination has grown into a mass tourism destination. Society no longer welcome tourists, away from the attitude and helpful. At this stage it is usually the type of tourists who come will be changed; (5) characterized by the embracement of the community were very supportive of tourism, occur in groups of people who receive benefits directly from tourism; (6) Tolerance describe people who are tolerant of the negative impacts of tourism activities; (7) Adjustment describe the attitude of society to accept coexistence with tourism and showed no positive or negative feelings towards tourism. (8) Withdrawal describe communities tend to be silent.

Irridex theory of Doxey is used to answer the formulation problems associated with the existing first tourism in terms of attitudes or public response to tourism practices that took place in the Baha Tourism Village in Badung regency.

\section{Rural Tourism Model}

Rural tourism models that can be developed in Indonesia are grouped based on the two-pronged approach, which is based on product characteristics and the characteristics of tourism development. Rural tourism model approach cited in the book village and Culture in Tourism Frame (Sewoyo, et al, 2011).

\section{Rural Tourism Model Approach Based of The Tourism Product Characteristics}

The model is based on the characteristics of the tourism product is divided into two, namely active and passive travel activity. Based on the characteristics of tourism activities, rural tourism is divided into two, which is based on the types of interactions with the community and the nature of activities to be a reference to a model of rural tourism which in terms of the characteristics of tourism products and developing in Indonesia. The model of rural tourism based on the characteristics of tourism products are translated into three types with the characteristics of each. In diagrammatic, rural tourism models on display in the form of Matrix1. 


\section{Matrix 1. \\ Rural Tourism Model Approach Based Characteristics of The Tourism Product}

\begin{tabular}{|c|c|c|}
\hline \multirow{2}{*}{ Interaction type } & \multicolumn{2}{|c|}{ Character of Tourism Activity } \\
\hline & Active & Passive \\
\hline Full Interaction & $\begin{array}{l}\text { a. Travelers interacts } \\
\text { full of life and culture of } \\
\text { rural communities as a } \\
\text { whole. Rural tourism } \\
\text { activities offered are tourist } \\
\text { activities are active, } \\
\text { meaning that travelers are } \\
\text { actively involved in tourism } \\
\text { activities }\end{array}$ & $\begin{array}{l}\text { There is no model like } \\
\text { this (full Interaction } \\
\text { definitely active nature of } \\
\text { its activities) }\end{array}$ \\
\hline $\begin{array}{l}\text { Half-Full } \\
\text { Interaction }\end{array}$ & $\begin{array}{l}\text { a. Traveller } \\
\text { interactions with the public } \\
\text { is limited. Rural tourism } \\
\text { activities offered are tourist } \\
\text { activities are active, } \\
\text { meaning that travel actively } \\
\text { involved in tourism } \\
\text { activities. }\end{array}$ & $\begin{array}{l}\text { Traveller interactions } \\
\text { with the public is limited. } \\
\text { Rural tourism activities } \\
\text { offered are wxisata } \\
\text { passive activity. }\end{array}$ \\
\hline
\end{tabular}

Source: Siswoyo, et al (2011).

\section{Rural Tourism Model Approach Based of The Development Characteristics}

In addition based on characteristics of tourism products, further approaches on the model of rural tourism development are reviewed based on the characteristics. Based on the characteristics of the development model of rural tourism consists of six models that describe the process of planning and management system of rural tourism. These six models and indicators of each model of rural tourism development based on the characteristics described in Matrix 2 below.

\section{Matrix 2}

\section{Rural Tourism Model Approach Based of The Development Characteristics}

\begin{tabular}{|c|c|c|c|c|}
\hline \multirow{2}{*}{$\begin{array}{l}\text { Num } \\
\text { ber }\end{array}$} & \multicolumn{3}{|c|}{$\begin{array}{l}\text { Rural Tourism Model Approach } \\
\text { Based of The Development } \\
\text { Characteristics }\end{array}$} & \multirow{2}{*}{ Indicators } \\
\hline & initiator & Manager & $\begin{array}{l}\text { Manageme } \\
\text { nt System }\end{array}$ & \\
\hline 1 & $\begin{array}{l}\text { Commu } \\
\text { nity }\end{array}$ & $\begin{array}{l}\text { Communit } \\
\text { y }\end{array}$ & Individual & $\begin{array}{l}\text { a. Evolved at the initiative of } \\
\text { the village community. Managed } \\
\text { individually. The management } \\
\text { system is fully within the authority } \\
\text { of society. }\end{array}$ \\
\hline 2 & $\begin{array}{l}\text { Commu } \\
\text { nity }\end{array}$ & $\begin{array}{l}\text { Communit } \\
\mathrm{y}\end{array}$ & group & $\begin{array}{l}\text { a. Evolved at the initiative of } \\
\text { the village community. Managed in }\end{array}$ \\
\hline
\end{tabular}




\begin{tabular}{|c|c|c|c|c|}
\hline & & & & $\begin{array}{l}\text { groups by the villagers alone or in } \\
\text { cooperation with other parties. The } \\
\text { management system is fully within } \\
\text { the authority of society. }\end{array}$ \\
\hline 3 & $\begin{array}{l}\text { Commu } \\
\text { nity }\end{array}$ & $\begin{array}{l}\text { Non } \\
\text { Communit } \\
\text { y }\end{array}$ & & $\begin{array}{l}\text { a. Evolved at the initiative of } \\
\text { the village community. Managed } \\
\text { by the non villagers (private, } \\
\text { public). The management system is } \\
\text { fully within the authority the owner } \\
\text { or manager of non community. }\end{array}$ \\
\hline 4 & $\begin{array}{l}\text { Non } \\
\text { Commu } \\
\text { nity }\end{array}$ & $\begin{array}{l}\text { Communit } \\
\mathrm{y}\end{array}$ & Individual & $\begin{array}{l}\text { a. Evolved at the initiative of } \\
\text { outsiders, not villagers (private, } \\
\text { public). Managed individually by } \\
\text { the villagers, and full management } \\
\text { system is a public authority owner } \\
\text { or manager. }\end{array}$ \\
\hline 5 & $\begin{array}{l}\text { Non } \\
\text { Commu } \\
\text { nity }\end{array}$ & $\begin{array}{l}\text { Communit } \\
\mathrm{y}\end{array}$ & group & $\begin{array}{l}\text { Initiated by parties outside of the } \\
\text { village community, in this case } \\
\text { usually is the investor. Managed } \\
\text { individually. The management } \\
\text { systems are not spontaneous, that is } \\
\text { managed by professional } \\
\text { management. Society only act as } \\
\text { labor or lessor of rural tourism } \\
\text { facilities. }\end{array}$ \\
\hline 6 & $\begin{array}{l}\text { Non } \\
\text { Commu } \\
\text { nity }\end{array}$ & $\begin{array}{l}\text { Non } \\
\text { Communit } \\
\text { y }\end{array}$ & - & $\begin{array}{l}\text { Evolving over the initiative from } \\
\text { the outside, not the villagers } \\
\text { (private, public). Managed by the } \\
\text { non-community villages (private, } \\
\text { public). The management system is } \\
\text { fully within the authority the owner } \\
\text { or manager of non-community. }\end{array}$ \\
\hline
\end{tabular}

Source: Siswoyo, et al (2011).

The rural tourism model is becoming the core concepts and become a major topic in this study. With the aim, this model will be applied in the tourism development in the Baha Tourism Village.

\section{Methodology}

This study used descriptive qualitative method. Because this research is qualitative research, so that the population and sampling in this study is defined as the determination of resources (Joseph, 2014). Mechanical determination of the source of information (informants) to be used as the data source by using purposive sampling .. The data used is qualitative data in the form of a data description information is described in detail on the general picture and Tourism Village Baha-depth interviews with informants and quantitative data that is data in the form of numbers that can be calculated, such as data tourists visiting the Badung regency, monographs, Baha Village. Both types of data derived from 
primary data that the informants who have been determined and the primary data such as the results of direct observation Tourism Village Baha and result-depth interviews with informants also secondary source of data that is archived Perbekel village of Baha, examine the results of previous studies and literature books which has been linked to rural tourism as a book village and Culture in Tourism Frame (Sewoyo, et al, 2011) and the Tourism Village Baha, monographs, and books Baha Village Champion (Soethama, et al, 1995). Data obtained by observation, interviews, and documentation. The data were analyzed qualitatively further illustrated by descriptive technique. The analysis used during the field in this study refers to the model of Miles and Huberman (in Sugiyono, 2014).

\section{Results and Discussion}

Existing of tourism condition in Baha Tourism Village that has been identified is a tourist attraction that still exist in the form of a panoramic expanse of rice fields of natural attractions and cultural attractions of visiting the traditional house belonging to some local communities. Although accessibility is actually very supportive in terms of where vehicles are hot mix asphalt and some paving, Baha Village also be a shortcut to several destinations such as Pura Taman Ayun, Sangeh, Bedugul, Ubud, Tanah Lot and Singaraja. Amenities in Baha Tourism Village such as homestay managed by Mr. I Ketut Jaya but allocation can not run because of lack of tourist visits to the Tourism Village Baha. For a restaurant or restaurant in the Baha village tourism still very minimal and micro-scale in the form of a grocery shop or shop cart. Supporting facilities at the Baha Tourism Village is also available as a public toilet and wantilan and some infrastructure such as clean water, electricity and communication networks that are already available can be a support tourism practices in the Baha Tourism Village. From the institutional side, the lack of synergy and execution responsibilities, roles and functions of each stakeholder optimally. Tourist activities that exist that look at a traditional Balinese house owned by local communities and enjoy coffee breaks at the traditional house. Baha Tourism Village actually not have a program that developed its own travel. A visit to the Baha Tourism Village that still exist until now a guest's request or initiative from the tour guide its offer optional tour.

Existing Tourism of Baha Tourism Village in terms of destination life cycle, Baha Tourism Village development is currently in the stages of involvement. In this phase already existed local community investment for basic facilities of tourism, tourists are still rare. Promotion has been done on a small scale. The government started to invest in infrastructure. The facts at the Baha Tourism Village that their investment in the provision of tools art and mini stage art performances by Mr. Ida Bagus Alit, an improvement of reeds on angkulangkul, Bale Badung and Jineng conducted on the initiative of Mr. I Made Kupig, the provision of homestay managed by Mr. I Ketut Jaya, tourist arrivals are still very rare in a short time and even just seen crossing alone, tourist arrivals also sporadic, sometimes appear suddenly, sometimes none, the promotion has been done by Disparda Badung either in the form of booklets, profile books of Badung Tourism Office, website, appears blogspot or travel web that promotes Baha Tourism Village to provide travel packages VW Tour or just describe briefly the Baha Tourism Village, infrastructure that has been built among others: public 
toilets, repairs road axis or trekking in the village road construction Tourism Baha, and street lighting.

Public response to the activities of tourism at the Baha Tourism Village is currently still at the phase of withdrawal (people who tend to be quiet) in the Theory of Irritation Index. Facts Baha Tourism Village shows people tend to be quiet, passive and anxiety because of the vagueness of existence Tourism Village Baha, the lack of initiative of the owners of traditional houses to diversify tourism products, homeowners traditionally only be spectators, expression indifferent when there are no tourists passing Baha village.

Viewed existing and phenomena that occur in the practice of tourism at the Baha Tourism Village can be said of tourist activities in the Baha village has the half-full interaction. The characteristics of rural tourism where tourists only limited interaction with village life and tourism activities that do matter are passive like see- see the rice terraces in the Baha Tourism Village and see a traditional house in the Baha Tourism Village. Characteristics of rural tourism activities at the Baha Tourism Village was still passive. Tourism Village activities in the form of a visit to the Baha traditional houses that do not involve tourists in production. Travelers simply be a spectator of tourist activities developed in the Baha Tourism Village like to look around the traditional Balinese house in the Baha Village Tourism.

Passivity practice rural tourism at the Baha Tourism Village was supported by the results of an analysis of the existing public attitudes toward the practice of tourism at the Baha Tourism Village which shows the withdrawal phase (people who tend to be quiet). Local people who become actors of tourism as well as passive or tend to remain silent. This happens because of a lack of language skills and knowledge of the tourism products on offer. Both actually are capital in building an active interaction between local people and tourists. Correspondence between the phenomenon and tourism practices that occur at the Tourism Village Baha indicator on the rural tourism models areas is a key analysis in this study to get a portrait of the village of Baha based on the product characteristics of tourism leading to the model of tourism in rural interaction semipenuh-passive namely tourism rural areas to the condition of tourists just do limited interaction with the life and culture of rural communities, and tourist activities were done too passive, like to see the sights and rural life.

Judging by the characteristics of its development, a man with early initiation is the Regent of Badung (I Gusti Bagus Alit Putra period of office from 1990 to 1995 continued from 1995 to 2000) and was developed by the Head of Baha Village (Perbekel) at that time (Mr. I Wayan Kertiana). When examined, at the time of the launching of the two figures have in common the responsibility of ownership and power in the realm of government although at different levels. Mr. Gusti Alit Putra who has duties and functions as the leader of the regional government of Badung regency (Bupati) whereas Mr. I Wayan Kertiana carry out their duties and functions as a leader in the area of the Baha Village government ( Head Village / Perbekel). It can be concluded The initiators are non-public, or more precisely from the government. When viewed from the overall potential and existing tourist attraction since the enactment as a Baha Tourism Village but that still exists to this day there are only two major tourist attraction is the panoramic expanse of paddy fields in the Baha Village Tourism and traditional home visits. 
Both the existing tourist attraction at the Baha Tourism Village it was managed independently or individually by the local community. Portrait of rural tourism model the Baha Tourism Village when seen from the characteristics of the development initiated by non-community (local government and village governments) and managed by the individual societies. Existing models of rural tourism at the Baha Tourism Village describes the development of tourism practices not in accordance with the expectations of society and inisiatornya and eligible regarded as ideal tourist village.

\section{REFERENCES}

Arikunto, Suharsimi, 2010. Prosedur Penelitian Suatu Pendekatan Praktek, Jakarta: Penerbit Rineka Cipta.

Buhalis, D. (2000). Marketing The Competitive Destination Of The Future. Tourism Management, Tourism Management Journal Vol 21 , No 1 (2000), 97-116. Amsterdam: Elsevier B.V.

Moleong, L. J. 2012. Metodelogi Penelitian Kualitatif (Edisi Revisi). Bandung: PT Remaja Rosdakarya

Muliadiasa, I Ketut. 2008. Strategi Pengembangan Desa Baha Kecamatan Mengwi Kabupaten Badung menjadi Desa Wisata (Tesis). Denpasar: Program Pascasarjana Universitas Udayana.

Nugroho, Saptono. 2014. Praktik Geowisata di Karangsambung dari Perspektif Dualitas (Tesis). Denpasar: Program Pascasarjana Universitas Udayana Denpasar.

Pitana, I Gede dan Putu Gayatri. 2005. Sosiologi Pariwisata. Yogyakarta: Penerbit ANDI

Pujaastawa, I.B.G, Wirawan, I.G.P, dan Adhika, I.M. 2005.Pariwisata Terpadu: Alternatif Model Pengembangan Pariwisata Bali Tengah. Badung: Universitas Udayana Kampus Bukit Jimbaran Kabupaten Badung, Bali.

Samiarta, I Gede. 2015. Perkembangan Desa Wisata di Kabupaten Badung (Studi Kasus Desa Wisata Baha) (Laporan Penelitian Lapangan III). Denpasar: Program Studi S1 Destinasi Pariwisata Fakultas Pariwisata Universitas Udayana Denpasar.

Sewoyo, H, Alfian, Faruk, dan Priya Falaha (ed). 2011. Desa dan Budaya dalam Bingkai Pariwisata. Jakarta: Pusat Penelitian dan Pengembangan Kepariwisataan Badan Pengembangan Sumber Daya Kementrian Pariwisata dan Ekonomi Kreatif.

Soethama, Aryantha dan Malihana, Pande (ed). 1995. Sang Juara: Sembilan Desa Terpilih di Bali. Denpasar: Biro Humas dan Protokol Setwilda Tk.1 Bali. 
Sugiyono. 2014. Metode Penelitian Kombinasi (Mixed Methods). Bandung: Penerbit Alfabeta.

Suryawan, Ida Bagus, Suryasih, Ida Ayu, dan Anom, I Putu (ed). 2016. Perkembangan dan Pengembangan Desa Wisata. Bogor: Percetakan dan Penerbit Herya Media.

Yusuf, Muri. 2014. Metode Penelitian Kuantitatif, Kualitatif, dan Penelitian Gabungan.Jakarta: Kencana 